\title{
Buddy Guy ja blueskitaransoiton salaisuudet
}

Tässä artikkelissa tarkastelen Buddy Guyn 1960-luvulla levyttämien 12-tahtisten blueskitarasoolojen soittotekniikoita ja rakenneperiaatteita. Guy on yksi tunnetuimmista 1950-luvun loppupuolella Chicagossa levytysuransa aloittaneista sähkökitaristeista ja on omalla nimellään julkaistujen äänitteiden lisäksi soittanut myös monien muiden merkittävien taiteilijoiden levyillä $\mathrm{mm}$. toimiessaan Chess-yhtiön puolivakituisena sessiomuusikkona. Vaikka hänen tyylinsä onkin selvästi tunnistettava ja persoonallinen, on siinä myös tiettyä yleispätevyyttä. Lukuisten muiden ikäpolvensa sähkökitaristien tavoin hänen soitossaan on kuultavissa erityisesti T-Bone Walkerin ja B.B. Kingin sekä hieman vähemmän tunnetun Guitar Slimin vaikutus, ja kun vielä todetaan Guyn soittavan tavanomaista sähkökitaraa oikein päin, normaalivirityksellä ja plektraa apuna käyttäen, voidaan katsoa kyseessä olevan miltei poikkeuksellisen tavanomainen soittaja. (ks. esim. Obrecht 1990.)

Tutkimustulokset ovat näin ollen varovasti yleistettävissä laajemminkin blueskitaransoittoa koskeviksi. Analyysin pohjaksi olen kartoittanut bluesia käsitteleviä tutkimuksia sekä toisaalta kitaransoittoa ja improvisointia koskevia kirjoituksia. Oletukseni on, että bluessoolojen soitto sähkökitaralla, kuten luultavasti myös ainakin kosketinsoittimilla 
ja huuliharpulla, tapahtuu voimakkaammin soittimen ehdoilla kuin mitä asteikkolähtöiset selitysmallit antavat ymmärtää. Instrumentin rakenne ja viritys sekä ajan myötä kehittyneet soitinkohtaiset soittotekniikat vaikuttavat käsittääkseni soivaan lopputulokseen enemmän kuin esimerkiksi jokin bluesasteikoksi kutsuttu abstraktio.

Tutkimuskohde on historiallisesti merkittävä, sillä toisen maailmansodan jälkeinen Chicagoblues on voimakkaasti vaikuttanut populaarimusiikin kehitykseen. Ensinnäkin se on yksi tärkeimmistä rockmusiikin syntyyn johtaneista tyyleistä, tekiväthän esimerkiksi Bo Diddley ja Chuck Berry ensimmäiset levytyksensä chicagolaiselle bluesmerkille, Chessille. Tämä tyyli toimi myös esikuvana monille 1960-luvun brittiläisille rockyhtyeille, mikä vaikutus heijastui takaisin USA:han näiden yhtyeiden noustua siellä suosituiksi. Erityisesti monet rockkitaran pioneerit kopioivat suoraan vanhempien bluesmiesten tekniikoita ja fraaseja.

\section{Kuka?}

1960-luvun taitteessa Buddy Guyta pidettiin yleisesti ehkä Chicagon lupaavimpana nuorena blueskykynä. Guyssa yhdistyivät pistävän diskanttinen, tunnistettava kitarasoundi ja energinen soittotyyli sekä soulvaikutteinen, kiihkeän tunnepitoinen laulutapa. Lisäksi hän oli sangen vaikuttava lavaesiintyjä. Muusikkona Guy oli vahvasta persoonastaan huolimatta varsin sopeutumiskykyinen, niinpä hän esiintyi ja levytti erittäin monien iuon ajan nimekkäiden bluesartistien kanssa. 1960-luvun bluesboomi nosti hänet myös valkoisten tietoisuuteen ja monien rockkitaristien esikuvaksi Hendrixistä ja Claptonista lähtien.

Mielikuva menestyvästä bluestähdestä on kuitenkin osin harhaanjohtava. Listalle Guyn levytyksistä nousi ainoastaan joulukuussa 1961 äänitetty Stone Crazy, ja ensimmäisen varsinaisen oman Ip-levyn hän teki vasta 1967. Guy onkin monissa haastatteluissa valitellut, ettei hänellä ole tehtynä levyä, joka todella tekisi hänelle oikeutta (ks esim. O'Neal-Zorn 1970:8; Obrecht 1990:37, 47). Kun sitten suuremman yleisön bluesinnostus 1970-luvulle tultaessa hiipui, tuntui aika ajaneen Guyn ohi. Vielä 1979 Guy äänitti ranskalaiselle Isabel-merkille Ip:n Stone Crazy, joka tosin sittemmin julkaistiin myös Yhdysvalloissa chicagolaisella Alligator-merkillä, mutta 1980luvulla ei tehty yhtään uutta äänitettä. 1990-luvun alku sen sijaan 
näyttää taas valoisammalta. Guitar Player -lehden numero 4/1990 oli erityinen bluesnumero, jonka pääartikkeli, Buddy Guyn haastattelu, nosti vanhan mestarin taas suuremman yleisön tietoisuuteen. Vuonna 1991 tuli markkinoille vahvasti tuotettu levy Damn Right, I've Got The Blues, jossa Guyn lisäksi soittaa myös häntä esikuvanaan pitäneitä rockmuusikoita, ja levyä on seurannut esiintymiskiertueita myös Yhdysvaltain ulkopuolella. Kesällä 1992 Guy esiintyi myös Suomessa Järvenpään Puistobluesissa.

George "Buddy" Guy syntyi Lettsworthissa, Louisianassa 30. 7. 1936. Hänen ensimmäiset kitaransa olivat milloin mistäkin tarpeista itse kyhättyjä viritelmiä, kunnes isä osti hänelle kolme dollaria maksaneen soittimen. Näillä instrumenteilla teini-ikäinen Buddy opetteli soittamaan levyiltä ja radiosta kuulemiensa Lightnin' Hopkinsin, John Lee Hookerin ja T-Bone Walkerin musiikkia. Ensimmäisen oikean kitaran Guy sai Mitchell nimiseltä maankiertäjältä, joka tarvitsi kitaristia säestämään lauluaan. He soittivat viikonloppuisin Baton Rougen seudulla, kunnes Mitchell katosi teilleen. Kitara jäi Buddylle, ja hän soitteli huoltoasematyön ohessa lähinnä paikallisten nuorempien muusikoiden kanssa. Arvokasta esiintymiskokemusta Guy sai, kun paikkakunnan ehkä tunnetuin muusikko ja disc jockey John "Big Poppa" Tilley kiinnitti hänet yhtyeeseensä. Big Poppan yhtyeessä Guy pääsi säestämään monia nimiartistejakin kuten Lightnin' Slim (Otis Hicks), Lazy Lester (Leslie Johnson) ja Slim Harpo (James Moore). (Rowe 1973:179.)

Vuonna 1957 Guy muutti Chicagoon. Kaupungissa oli valtavasti bluesmuusikoita, eikä nuoren, vasta etelästä tulleen kitaristin ollut helppo saada itseään esiin. Lopulta hän kuitenkin pääsi kitaristiksi ja laulajaksi saksofonisti Rufus Foremanin yhtyeeseen, joka esiintyi säännöllisesti Chicagon bluesklubeilla. Useissa lähteissä pidetään Guyn uran käännekohtana voittoa Blue Flame -klubilla pidetyssä Battle Of The Blues -kilpailussa, jossa osanottajina olisivat olleet myös ainakin Magic Sam Maghett ja Otis Rush (ks. esim. Rowe 1973:180; Hannusch 1989:306). Guy itse puhuu haastatteluissa Battle Of The Guitars -kilpailusta, muttei aseta sille niin suurta painoa uransa kannalta kuin varhaiselle esiintymiselleen B.B. Kingin kanssa 708 Clubilla vuonna 1958, mikä kerralla lisäsi hänen tunnettavuuttaan Chicagon bluespiireissä (O'Neal-Zorn 1970:4.).

Magic Sam Maghett suositteli Guyta Cobra Recordsin johtajalle, Eli Toscanolle, ja Guy teki Cobran alamerkille Artisticille kaksi singleä, 
joissa olivat kappaleet Sit And Cry ja Try To Quit You Baby (Artistic 1501) sekä This Is The End ja You Sure Can't Do (Artistic 1503). Taustayhtyeessä näillä levyillä soittivat myös mm. Otis Rush ja Willie Dixon. Guyn oma tyyli oli näillä levyillä jo lähes valmis: hänen soittonsa toi mieleen lähinnä Guyn tapaan louisianalaisen Guitar Slimin sekä etäisesti B.B. Kingin, mutta se oli jollain tapaa nuorekkaampaa ja energisempää, mikä erityisesti lienee myöhemmin kiinnittänyt juuri rockmuusikoiden huomiota.

Toscano murhattiin 1959, ja Cobra/Artistic lopetti toimintansa. Willie Dixon järjesti Rushille ja Guylle sopimukset Chessin kanssa, ja Guyn ensimmäinen levytyssessio tälle yhtiölle pidettiin maaliskuussa 1960. Näissä levytyksissä, joista tunnetuimmat lienevät First Time I Met The Blues ja Broken-Hearted Blues, laulu kulkee aivan falsetin rajoilla ja ylikin, ja kitarafraasit koostuvat nopeista ryöpsähdyksistä, jotka vibrakammen runsas käyttö saa kuulostamaan ajoittain lähes epävireisiltä. Esitykset ovat intensiivisyydessään todella vaikuttavia. Guy kohosikin nopeasti Leonard Chessin ja Willie Dixonin luottomieheksi, ja huomasi pian levyttäneensä lähes kaikkien yhtiön merkittävien muusikoiden kanssa, joskus jopa basistina. Vaikka kirjoittajat yleensä luokittelevat hänet Magic Samin ja Otis Rushin kanssa samaan West Siden tyyliin, on hän itse aina korostanut arvostaneensa nimen omaan Muddy Watersia ja muita vanhempia South Siden tyylin muusikoita, jotka tekivät raskaan pioneerityön siirryttäessä akustisesta sähköisesti vahvistettuun musiikkiin.

Vaikka Guy yhtyeineen levyttikin ahkerasti, ei hän itse Chesskaudellaan tehnyt yhtään omaa Ip-levyä ja muidenkin kanssa tehdyistä äänitteistä useimmat olivat singlejä. Myöhemmin näistä tosin on julkaistu useitakin kokoelmia. Guyn yhtyeen jäsenet vaihtelivat jonkin verran, mutta peruskokoonpano pysyi useimmiten samantyyppisenä: rummut, basso, piano ja puhallinsektio. Joskus mukana oli myös rytmikitaristi, urkuri tai huuliharpisti. Rumpuja soitti varsinkin alkuaikoina yleensä Fred Below, myöhemmin mm. Al Duncan tai Clifton James, bassoa Jack Myers ja pianoa tavallisesti Otis Spann tai Lafayette Leake. IImeisesti juuri Leonard Chess tahtoi Guyn levyttävän tällaisen keskisuuren, puhaltimilla vahvistetun yhtyeen kanssa, koska katsoi tämän kilpailevan markkinaosuuksista Motownin menestyvien nuorten mustien artistien kanssa.

1960-luvun puoleen väliin tultaessa Buddy Guyn muusikonelämä muuttui kaksinapaiseksi. Lähinnä valkoisen nuorison bluesinnostuk- 
sen noustua hän kiersi esiintymässä yliopistokonserteissa, jazzfestivaaleilla ja konserttikiertueilla myös Euroopassa ja Afrikassakin. Kiertueiden ja konserttien välissä hän esiintyi omalle yleisölleen Chicagon South Siden pienissä klubeissa, tavallisesti Theresa'sissa tai Pepper'sissä. (Hannusch 1989:307.) Näihin aikoihin alkoi myös tiiviimpi yhteistyö huuliharpisti Amos "Junior" Wellsin kanssa. Lähes kymmenen vuoden ajan he julkaisivat musiikkiaan noin yhden Ip:n vuosivauhdilla sekä tekivät laajoja konserttikiertueita. Suomessa he ovat esiintyneet kahdesti: Rolling Stones -yhtyeen kakkosesiintyjinä Olympiastadionilla vuonna 1970 sekä Tavastiaklubilla 1980-luvun puolivälissä.

Vuonna 1967 Buddy Guy siirtyi Chessiltä Vanguardille ja teki ensimmäisen oman Ip-levynsä. A Man And The Blues -levyn tuotti bluestutkija Samuel Charters, ja sillä soittavat pitkälti samat muusikot kuin aiemmilla Chess-äänitteilläkin. Levy on erittäin edustava esimerkki Guyn 1960-luvun tyylistä. Muutoinkin 1960-luvun loppu oli Guyn uralla tuottoisin kausi. Vaikka yhteistyö Wellsin kanssa oli tiivistä, teki hän Vanguardille vielä kaksi omaa levyä, ja nyt myös Chess kokosi hallussaan olevista Guyn esityksistä muutaman Ip:n. Vuonna 1966 hän teki Junior Wellsin esimerkin rohkaisemana sopimuksen Avalon Productions -ohjelmatoimiston kanssa, minkä ansiosta hän pääsi säännöllisesti myös esiintymään (O'Neal-Zorn 1970:6). Mustan väestön keskuudessa blues kuitenkin näytti huolestuttavasti menettävän suosiotaan.

1970-luvulla myös valkoisten bluesinnostus laantui. Levytykset harvenivat, samoin esiintymiskiertueet. 1979 hän äänitti Ranskassa Ip:n Stone Crazy, jota hän itse piti vielä 1990 Guitar Player -lehden haastattelussa parhaana levynään (Obrecht 1990:37). 1980-luvulla Guy ei tehnyt yhtään levyä, mutta esiintymistä hän jatkoi sekä omalla yhtyeellään että Wellsin kanssa. 1989 hän avasi Chicagossa oman Legends-nimisen klubin, jossa hänen vieraanaan on esiintynyt lukuisa joukko bluesin ja rockin suuria nimiä, ja tämä pohjusti Guyn uutta tulemista. 1991 ilmestyi Buddy Guyn toistaiseksi viimeinen levy: Damn Right, I've Got The Blues. Guyn lisäksi sillä soittavat kitaraa mm. Mark Knopfler, Jeff Beck ja Eric Clapton, rumpalina on Richie Hayward Little Feat -yhtyeestä, ja lisäksi levyllä on vielä Memphis Horns -puhallinsektio. Levyn vanavedessä on Woodford-kustantamolta tulossa markkinoille myös elämäkertateos Don't Start Me To Talkin': Buddy Guy And The Blues Roots Of Rock And Roll, jonka tekijöiksi on ilmoitettu Donald E. Wilcock ja Buddy Guy. 


\section{Analyysimetodi}

Tehdyn tutkimuksen painopistealueissa ei blues juurikaan eroa muusta populaarimusiikin tutkimuksesta: mitään bluesin aspekteista ei ole niin laiminlyöty kirjoittajien keskuudessa kuin idiomin analyysiä musiikkina (ks. esim. Oliver-Harrison-Bolcom 1986:158). Bluesia on toki tutkittu, mutta näkökulma on useimmiten kulttuuri- tai sosiaalihistoriallinen. Vaikka erityisesti instrumentalisteille tarkoitettua, varsin vaihtelevan tasoista opetusmateriaalia on julkaistu kohtalaisen paljonkin, on musiikkitieteellisiä analyysejä aivan muutama. Tällaisista analyyseistä Paul Oliver mainitsee Faheyn, Titonin ja Evansin tutkimukset, jotka kaikki käsittelevät Mississippin Deltan countrybluesia. Näistä oman työni kannalta tärkein on Titonin Early Downhome Blues (1979), jossa Titon johtaa tekemistään lähes 50 transkriptiosta blueslauluja tuottavan generatiivisen mallin.

Analyysikorpukseen valitsemistaan kappaleista Titon on valinnut nuotinnettavaksi yleensä yhden laululle tyypillisen säkeistön. Jos laulaja muuntelee melodiaa merkittävästi tai jos joissakin säkeistöissä on kokonaan eri melodia, on mukaan otettu useampia säkeistöjä; muutamat laulut on nuotinnettu kokonaan. Analyysia varten on kaikki transkriptiot transponoitu vertailun mahdollistamiseksi c-sävellajiin. Nuotinnoksissa on otettu huomioon puoliaskelta pienemmät sävelkorkeuden muutokset ja vähäisetkin tempovaihdokset jopa yksittäisten sävelten kohdalla. Transkriptioista Titon erittelee aluksi laulujen rytmisten rakenteiden pääpiirteet sekä johtaa melodia-analyysin mahdollistavan bluesasteikon.

Bluesin omaleimainen tonaliteetti on johtanut kirjoittajia toinen toistaan hämärämpiin ja mystisempiin selityksiin ja määritelmiin. Yleensä bluesia on pidetty erityiseen bluesasteikkoon pohjautuvana musiikkina karakteristisina sävelinään ns. bluessävelet (blue notes). Titon valaisee blue note -käsitteen monimielisyyttä:

Valitettavasti he [muut tutkijaf] eivät ole keskenään yhtä mieltä siitä, mikä "blue note" on tai kuinka sitä käytetään. Joidenkin mielestä se on yksi sävel, toisten mielestä säveljoukko; vieläpä jotkut uskovat sen olevan liu'utus. Jotkut paikantavat sen "alennetuksi" terssiksi tai septimiksi, joka korvaa suuren intervallin; jotkut ottavat mukaan sekä "alennetun" (joskus erotettuna "pienestä") että suuren intervallin. (Titon 1979:155.) ${ }^{1}$ 
Titonin oma käsitys bluessävelistä perustuu hänen transkriptioihinsa, joista hän on laskenut jokaisen äänen esiintymien painotetun määrän. Painotettu arvo on saatu laskemalla yhteen nuottivarret; näin rytmisesti tärkeät äänet, kaaritetut synkoopit, saavat suhteessa suuremman arvon ja samoin korostuvat myös pitkät äänet. Tuloksena on esimerkin 1 mukainen asteikko. Termin blue note Titon korvaa termillä kompleksi (complex), joka paremmin ilmaisee, että kyseessä on sävelryhmä. Kompleksin yksittäisten sävelten esiintymistä määräävät niiden asema fraasissa sekä niitä edeltävät sävelet. (mts 154-156.) Itse käytän jatkossa nimityksiä terssikompleksi, kvinttikompleksi ja septimikompleksi.

Esimerkki 1. Jeff Titonin downhome blues -asteikko (Titon 1979:155)

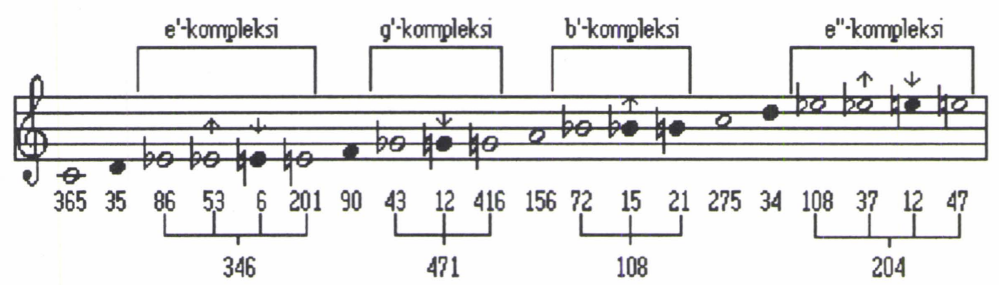

Titonin konstruoimassa bluesasteikossa kiinnittyy huomio erityisesti kompleksien sisäisiin suhteisiin: kun bluesin yhteydessä on monesti pidetty tärkeinä juuri pienen ja suuren terssin ja septimin sekä puhtaan ja vähennetyn kvintin välissä olevia ääniä (ks. esim. Kjellberg 1976, s. v. blue note; Backlund 1983:68; Eklund 1987:28-29), niin nyt nähdään painollisimpien sävelten olevan suuri terssi alemmassa ja pieni terssi ylemmässä terssikompleksissa, puhdas kvintti kvinttikompleksissa sekä pieni septimi septimikompleksissa.

Koska asteikosta selviävät vasta käytettävissä olevat sävelet, johtaa Titon sävelten painollisesta esiintymistiheydestä ja paikasta melodiakuvioissa hierarkkisen moodin, joka esittää niiden potentiaaliset käyttötavat ja liikkeet. Tämä moodikaan ei vielä anna riittävän tarkkoja todennäköisyyksiä sille, mikä yksittäinen sävel kulloinkin seuraa jotain tiettyä säveltä, niinpä Titon on tutkinut, millaisia melodisia hahmoja (melodic contour) esiintyy säkeistöjen, rivien ja säkeiden tasolla. Melodisen hahmon muodon määrittelevät sen ensimmäinen, viimeinen, korkein ja matalin sävel. 
Titon päättelee blueslaulajan noudattavan seuraavanlaista mallia tekstin ja melodian yhteensovittamiseksi: laulajalla on mielessään runkosävelmä (skeletal tune), jota hän tarpeen tullen modifioi korostaakseen painollisia tavuja melodisesti, rytmisesti ja dynaamisesti. Toisinaan laulajan täytyy melodisen linjan säilyttääkseen korostaa myös heikkoja tavuja. Runkosävelmän Titon määrittelee melodiaksi, joka laulussa olisi, jos sanoja ei tarvitsisi lausua. Runkoa itsessään tuskin lauletaan koskaan edes säkeistöissä, jotka hyräillään ilman sanoja, mutta se on johdettavissa lauletuista säkeistöistä. Mallin sisäistänyt blueslaulaja kykenee sijoittamaan painotettavat tavut oikeisiin kohtiin ja tarpeen tullen muuntelemaan kyseessä olevaa runkosävelmää sovittaakseen eri säkeistöjen erilaiset tekstijaot tyylinmukaisesti paikalleen.

Toisiaan muistuttavat runkosävelmät muodostavat bluesperheitä. Omasta analyysikorpuksestaan Titon löytää neljä bluesperhettä sekä esittää oletuksen, että suurempi otos olisi todennäköisesti saattanut myös nyt yksinäisiksi jääneistä lauluista ainakin suurimman osan jonkin perheen jäseneksi. Analyysinsä lopuksi Titon johtaa asteittain erään bluesperheen pohjalta mahdollisen runkosävelmän ja sovittaa siihen mielivaltaisesti valitusta kirjasta mielivaltaisesta kohdasta otetun lauseen rakentaen näin downhome blues -tyylisen säeparin.

Titonin analyysi on kauttaaltaan erittäin huolellisesti ja systemaattisesti tehty, ja mahdollisten ennakko-oletusten tai analysoijan oman hahmotustavan vaikutukset lopputulokseen on nähdäkseni melko tarkkaan minimoitu. Samaa ei valitettavasti voi sanoa niistä bluesin soittoa koskevista analyyseista, joihin olen tutustunut. On kuin soittajan olisi vaikeampi irroittautua omasta tavastaan käsittää instrumenttinsa ja musiikin välinen suhde; omaa musiikintekemistä säätelevä malli oletetaan yleiseksi, ja sen mukaisesti pyritään selittämään myös muiden soittoa.

Titonin menetelmän suora soveltaminen kitarasooloihin olisi kuitenkin suunnattoman suuritöinen, ehkä jopa mahdoton urakka. Kitarasoolojen säkeet eivät ole hengityksen, sanojen rytmityksen eivätkä laulajan äänialan rajoittamia, niinpä variaatiomahdollisuudet fraasien pituudessa, äänten rytmisessä järjestelyssä ja ambituksessa ovat huomattavasti moninaisemmat. Lisäksi laulujen melodiat pohjautuvat valmiisiin runkosävelmiin, kun taas kitarasoolot ovat luonteeltaan improvisatorisempia. Mainituista eroista huolimatta antaa Titonin menetelmä kuitenkin melko hyvän perustan äänimateriaalin analysoimiselle 
ja jonkinlaisen säännöstön luomiselle. Yhdenmukaisesti merkityt transkriptiot sekä suuremmista yksiköistä pienempiin systemaattisesti etenevä analyysi muodostavat rungon myös omalle tutkimukselleni.

Analyysiä varten olen nuotintanut yhdeksän Buddy Guyn 1960luvulla Chessille ja Vanguardille levyttämää 12-tahtista kitarasoolochorusta. Näistä kuusi on nopea- tai keskitempoisia, kolme on hitaita. Analyysimateriaalin pitämiseksi yhtenäisenä mutta kattavana on soolojen valinnassa käytetty kolmea pääkriteeriä:

1) kitarasoolon säestyksen tulee olla 12-tahtinen standardiblues

2) kitarasoolon tulee olla improvisoitu eli se ei saa noudattaa esimerkiksi laulun melodiaa kuin korkeintaan aloitusfraasin osalta

3) kitarasoolon tulee olla levytetty 1960-luvulla

Transkriboinnissa on käytetty apuvälineenä nauhuria, jonka nopeutta voidaan hidastaa puolella, ja lisäksi CD-levyjen kohdalla on voitu käyttää hyväksi CD-soittimen nauhalenkkiä vastaavaa toimintoa, jolla määriteltävä kohta levyllä saadaan toistumaan uudestaan ja uudestaan. Nuottikuvan pitämiseksi mahdollisimman selkeänä on hitaat soolot kirjoitettu 12/8-tahtilajissa ja muut 4/4-tahtilajissa; muilta osin notaatio on pyritty pitämään mahdollisimman yhdenmukaisena. 12/8tahtilajimerkintä on tosin siinä mielessä ongelmallinen, että tahdin iskuala on kahdeksasosan sijasta pisteellinen neljäsosa: tahdissa lasketaan neljään ja jokainen isku jakautuu kolmeen. Sekä rytmejä että sävelkorkeuksia kirjoittaessani olen pyrkinyt maksimaaliseen tarkkuuteen, mikä tekee erityisesti hitaiden kitarasoolojen nuotinnoksista ehkä vaikeasti luettavia. Kompleksinen rytmiikka on kuitenkin osin näennäistä ja johtuu yleensä solistin tilapäisistä kiihdytyksistä tai hidastuksista yhtyeen soittaman tasaisen peruspulssin yllä.

Näistä transkriptioista olen aluksi konstruoinut Buddy Guyn käyttämät sormitukset. Tämä on tehty Titonin mallia noudattaen transponoimalla kaikki nuotinnokset ensin c-sävellajiin ja laskemalla sitten kunkin äänen esiintymien painotettu arvo (Titon 1979:154-155). Painotettu arvo on saatu kaarittamalla heikolla iskulla alkavat iskualaa pitkäkestoisemmat äänet ja epäiskulla alkavat synkoopit. Kun esiintymien määrä nyt lasketaan nuottivarsista, saavat pitkät äänet lyhyitä suuremman arvon. Transponointi ei kitaralla vaikuta sormitusten muotoon vaan ainoastaan niiden paikkaan otelaudalla. Toisaalta on muistettava, etteivät kitaran nauhat ole tasalevyisiä vaan kapenevat ylös- 
päin mentäessä, ja näin saman kuvion soittaminen oktaavilla transponoituna siirtämällä kättä 12 nauhaa haluttuun suuntaan voi teknisesti olla huomattavasti vaikeampaa soittokuvioiden näennäisestä samanlaisuudesta huolimatta.

Esimerkki 2. Buddy Guyn sormitukset

A

VIII

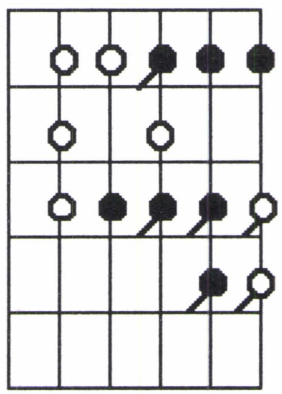

B
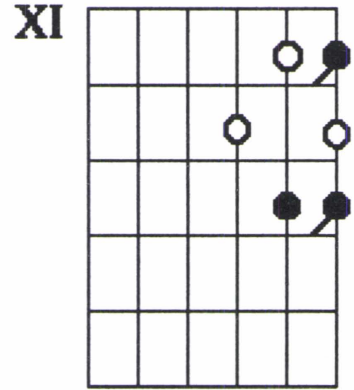

$\mathrm{C}$

XIII

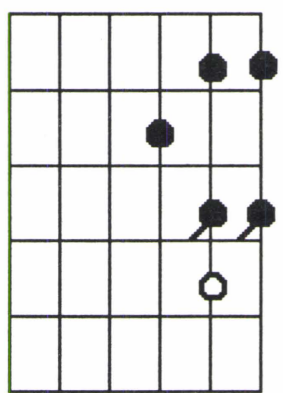

Jo transkriptioita tehtäessä kävi ilmi, että Buddy Guylla on 12-tahtisessa bluessoolossa käytössään kolme erilaista sormitusta. Näillä sormituksilla on kaikilla oma erityinen luonteensa: niistä ovat johdettavissa erilaiset asteikot ja omat tyypilliset soittokuvionsa. Niiden järjestys on myös esimerkkiotoksen sooloissa periaatteessa aina sama. Esimerkissä 2 ovat sormitusten otelautakaaviot. Umpinaiset pallot osoittavat kohtia, joihin sormet useimmin osuvat, ja pallosta lähtevä vinoviiva tarkoittaa, että kieltä voidaan venyttää kyseisestä paikasta. Periaatteessa olen ottanut mukaan kaikki soolojen soitetut äänet, mutta otelautakaavioista olen kuitenkin jättänyt pois sellaiset ilmeiset soittovirheet, jotka esiintyvät koko otoksessa vain kerran jonkin asemavaihdoksen kohdalla.

Koska mukana ovat ainoastaan analyysikorpuksen sooloissa aktuaalisesti soitetut äänet, eivät nämä sormitusmallit juurikaan muistuta kitaraoppaissa tavallisesti esitettäviä otelaudan läpi kulkevia asteikkosormituksia. Guyn soolot kulkevat miltei pelkästään kitaran ylimmillä kielillä, enkä ole katsonut tarkoituksenmukaiseksi jatkaa näitä sormituksia alaspäin esimerkiksi oktaavikerrannaisilla. Punomattomat ylä- 
kielet soveltuvat soolosoittoon alakieliä paremmin erottuvamman sointinsa ja tavallisesti myös alhaisemman jännityksensä vuoksi.

Tavallisesti kitaranuotit merkitään oktaavin soivaa ääntä ylemmäksi. Koska Buddy Guyn kitarasoolot liikkuvat suurimmaksi osaksi yläkielillä ja korkeilla sävelillä, olen kuitenkin katsonut selvimmäksi merkitä nuotit soivaan sävelkorkeuteen. Tabulatuurissa on käytetty hieman modifioitua Guitar Player -lehden systeemiä.

Nuoteista on käytetty anglo-amerikkalaisen käytännön mukaisia nimiä lähinnä kahdesta syystä: tämä järjestelmä on meillä yleisesti käytössäolevaa saksalaisperäistä systeemiä loogisempi ja lisäksi afroamerikkalaisen musiikin harrastajalle tutumpi. Tämän systeemin mukaan esimerkiksi kitaran kielet paksuimmasta ohuimpaan ovat standardivirityksellä $E, A, d, g, b, e^{1}$. Mollipentatonisella asteikolla tarkoitetaan analyysissa asteikkoa $c$, es, $f, g, b b$ ja duuripentatonisella asteikkoa $c, d, e, g$, a. Sävelistä on yleensä pyritty käyttämään intervallinimityksiä suhteessa perusääneen, koska ne ovat yleistettävissä kaikkiin sävellajeihin. Milloin kuitenkin sävelten nimet ovat käytössä, on nimen perustana käytetty nuotinnoksessa olevaa csävellajiin mahdollisesti transponoitua ääntä.

Soittotekniikoista olen käyttänyt ainakin puhekielessä vakiintunutta termistöä, joka ei ehkä ole kielitoimiston suositusten mukainen, mutta kylläkin ymmärrettävä. Osoittaakseni, etten ole keksinyt käsitteitä itse, lainaan tässä Ilpo Saastamoisen Kitarakirjassaan (1974) käyttämiä määritelmiä. Hieman liioitellen hän kirjoittaa kitaristien näppäävän "plektran ranneotteella keskimäärin joka kolmannen soivan sävelen ja loput vasemman käden venytyksillä, liu'uilla ja slurreilla" (mts:77). Slurri tarkoittaa kahden sävelen sitomista toisiinsa siten, että plektralla "näpätään vain ensimmäinen, ja toinen sävel saadaan soimaan pelkästään vasemman käden sormien avulla" (mts:94). Slurrit voivat olla alaspäisiä (pull off) tai ylöspäisiä (hammer on). Liu'uttaminen suoritetaan "näppäämällä sävel plektralla, jonka jälkeen sormi liukuu kieltä pitkin sitä samalla painaen päätössäveleen saakka, jota ehkä myös näpätään plektralla" (mts:95). Venytys puolestaan tapahtuu siten, että "kitaran kieli painetaan kiinni nauhaan ja sitä työnnetään tai vedetään kaulaan nähden poikkisuunnassa kohti viereistä kieltä" (mts:90), jolloin kielen jännitys kasvaa ja sävelkorkeus nousee.

Soolojen esittelyn jälkeen on ensin sormitukset analysoitu tarkemmin, ja tämän jälkeen on analyysimateriaalista pyritty löytämään muita yhteneväisyyksiä ja säännönmukaisuuksia. Titonin esi- 
merkin mukaan on ollut tarkoitus siirtyä asteittain suuremmista kokonaisuuksista pienempiin yksiköihin: kokonaisista sooloista sormituksiin, fraaseihin ja edelleen yksittäisiin motiiveihin tai soittokuvioihin. Tarkoituksena on ollut mahdollisimman tarkoin selvittää käytetyt soittotekniikat ja tyypilliset soittokuviot sekä myös yleisemmät rakenneperiaatteet.

\section{Kaksi esimerkkisooloa}

\section{Goin' Home (liite 1)}

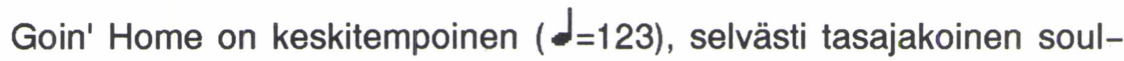
blues. Alun perin se julkaistiin Chess yhtiön kokoamalla Ip:llä Left My Blues In San Francisco (Chess LP 1527), joka koostuu Guyn tuolle yhtiölle äänittämistä kappaleista vuosilta 1962-67. Levy julkaistiin ilmeisesti vastineena Guyn Vanguard-yhtiölle tekemälle $A$ Man And The Blues -levylle, sillä kansiteksteissä väitetään levyn äänitetyn kokonaisuudessaan 1967, ja sitä markkinoitiin Guyn ensimmäisenä omana Ip:nä. Soolotranskriptioni on MCA:n CD-uudelleenjulkaisulta (CHD-31265), johon on lisätty tarkemmat tiedot äänitysajankohdista ja yhtyeistä.

Kappaleessa on ilmeisesti tavoiteltu tuon ajan blueslevyiksi erittäin hyvin myyneiden Albert Kingin Stax-yhtiölle tekemien äänitteiden henkeä. Yhtyeen sointi on pelkistetyn yksinkertainen: rummut ja basso dominoivat, piano ja tenorisaksofoni ovat selvästi taustalla. Myös Buddy Guyn kitarasoolossa on selviä vaikutteita Kingiltä, joskin Guy soittaa huomattavasti rauhattomammalla ja repivämmällä otteella. Sama persoonallisuuksien ero kuuluu myös laulussa: Kingin laulusoundi on matala ja rauhallinen, kun taas Guy revittää usein aivan äänialansa ylärajoilla.

Kappale alkaa neljän tahdin mittaisella introlla, joka kerrataan. Ensimmäinen, toinen ja neljäs säkeistö ovat 16-tahtisia laulusäkeistöjä, kolmas on 12-tahtinen kitarasoolo ja viides on kappaleen päättävä laulusäkeistö. Viidennen säkeistön säestys pysyy perustehossa, ja se päättyy häivytykseen. Guyn kitarasoundi on jälleen tyypillisesti diskanttipainotteinen.

Koko kitarasoolo on soitettu viimeistä lyhyttä fraasia lukuunottamatta B-sormituksella, ja soolon sävelvarasto on suppeahko: tahdin 
11 alkuun asti pysytellään kvintin sisällä ja suurimmaksi osaksi mollipentatonisen asteikon sävelillä. Fraasit alkavat joko perusäänellä tai venytyksellä sävellajin kvartista kvinttiin; ainoa poikkeus tästä on kymmenennessä tahdissa F7-soinnun päälle soitettu $\mathrm{f}^{2}$-sävelellä alkava fraasi. Fraseeraus on säestyksen lailla korostetun tasajakoista ja synkopoivaa, ainoat triolit ovat tahdeissa 8, 9 ja 11. Kitarasoolon alku on rauhallisempi, fraasit ovat lyhempiä ja tauot pitempiä, kun taas loppupuolella fraasit pitenevät, äänten kestot lyhenevät ja synkoopit lisääntyvät.

Soolo alkaa rauhallisesti ylöspäisellä terssihypyllä iskullisilla 1/4kestoisilla äänillä perusäänestä venyttämällä soitettuun duuriterssiin, minkä jälkeen jännitystä kasvatetaan yli tahdin mittaisella tauolla. Toisen tahdin viimeisellä kahdeksasosalla alkava fraasi nousee perusäänestä venyttämällä soitettuun kvinttiin ja palaa takaisin perusääneen. kolmannessa tahdissa on Albert Kingille tyypillinen motiivi, jota ovat soveltaneet lukemattomat blues- ja rockkitaristit, ja jota varioidaan myös tässä soolossa ahkerasti: venytys kvartista johonkin kvinttikompleksin ääneen ja hyppy molliterssistä perusääneen. Standardivirityksellä kvintti ja terssi soitetaan ylimmällä ja perusääni seuraavalla kielellä. Perusääntä edeltävä molliterssi on tyypillisesti lyhytkestoinen, muut äänet yleensä pitempiä.

Fraasi tahdissa viisi on edellä mainitun fraasin variantti. Se alkaa ensimmäisen iskun jälkimmäisellä kahdeksasosalla venytyksellä kvartista kvinttiin, putoaa molliterssin kautta toisella kielellä soitettuun perusääneen, ja tahdin viimeisellä iskulla on vielä hieman ylennetty molliterssi. Tahdissa kuusi alkava fraasi on muuten täysin samanlainen, mutta aloitussävel on lyhempi ja päätteeksi fraasi jatkuu vielä seuraavaan tahtiin. Ikään kuin ilmoituksena soinnun vaihtumisesta viimeinen sävel on venyttämällä soitettu duuriterssi.

Seuraava fraasi alkaa yllättäen jo seitsemännen tahdin viimeisellä kahdeksasosalla venyttämällä soitetulla kvintillä, josta pudottaudutaan edellisten fraasien tapaan molliterssin kautta perusääneen. $\mathrm{Pe}-$ rusäänestä noustaan vielä mollipentatonista asteikkoa ylöspäin takaisin venyttämällä soitettuun kvinttiin josta hypätään fraasin viimeiseen ääneen, molliterssiin. Fraasi on rytmisesti erittäin vaihteleva: se alkaa synkoopilla, tahdin ensimmäisen iskun lopussa on jo toinen synkooppi, ja tahdin kolmannella iskulla on shuffletrioli, joka jatkuu synkooppina seuraavaan iskuun. Fraasi päättyy tahdin viimeisen iskun toiselle kuudestoistaosalle. 
Seuraava fraasi alkaa yhdeksännen tahdin ensimmäisellä iskulla venyttämällä soitetulla hieman alennetulla kvintillä. Tahdin alussa on kaksi shuffletriolia, jotka on synkoopilla sidottu toisiinsa. Myös jälkimmäinen trioli on sidottu kolmanteen iskuun synkoopilla. Tahdin kolmannen iskun jälkimmäisellä osalla on alaspäinen slurri 1/32kestoisilla äänillä kvartista molliterssiin, ja kuvio jatkuu edelleen alaspäin perusääneen, josta noustaan tahdin päätteeksi molliterssiin takaisin.

Soolon viimeistä edellinen fraasi alkaa poikkeuksellisesti sävellajin kvartilla. Mahdollisesti soittajan tarkoitus on ollut korostaa säestyksenä olevaa subdominanttisointua. Seuraava ääni on hieman alennettu venyttämällä soitettu kvintti. Kymmenennen tahdin toisesta iskusta lähtien fraasi jatkuu pelkkinä synkooppeina tahdin 11 puoliväliin saakka. Tahdissa 10 laskeudutaan ensin mollipentatonista asteikkoa alaspäin perusääneen tahdin puolivälissä, minkä jälkeen noustaan taas samaa asteikkoa pitkin hieman alennettuun kvinttiin tahdin lopussa. Fraasin päätteeksi laskeudutaan jälleen molliterssin kautta perusääneen.

Soolon viimeinen fraasi on soitettu A-sormituksella. Asemaa vaihdetaan liu'uttamalla etusormella fraasin ensimmäisestä sävelestä alaspäin, minkä jälkeen vasta varsinaisesti soitetaan soolon päätösfraasi: venytetään kolmannella kielellä kvartista kvinttiin ja hypätään perusääneen ensimmäiselle kielelle, josta laskeudutaan mollipentatonista asteikkoa alaspäin. Viimeinen sävel on synkooppina soitettu molliterssi.

\section{Sweet Little Angel (liite 2)}

Sweet Little Angel on hidas (\rfloor$_{=53)}=53$ triolirytminen blues Ip:Itä A Man And The Blues. Kappale kuuluu bluesin tunnetuimpiin klassikoihin, ja myös Buddy Guy kertoo Guitar Player -lehden haastattelussa pitävänsä arvokkaimpina levyinään juuri B.B. Kingin Sweet Little Angelia ja Muddy Watersin Chess-levytyksistä koottua kansiota (Obrecht 1990:39). Kappaleessa on kuusi säkeistöä, ja se kestää yli viisi ja puoli minuuttia. Alku on vaikuttava: kitaran yksin soittama lyhyt koho johtaa ensimmäiseen kitarasoolochorukseen. Toinen ja kolmas säkeistö ovat laulettuja, neljäs on kitarasoolo, viides on laulusäkeistö ja kuudes eli viimeinen on jälleen kitarasoolo. Transkriptio on tehty neljännen säkeistön kitarasoolosta, koska tarkoituksena on ollut 
selvittää nimenomaan kitarasoolojen tyypillisiä rakenneperiaatteita ja koko kappaleen aloittava tai päättävä fraasi saattaisi vääristää kuvaa.

Guyn soolokitaran ja laulun lisäksi yhtyeen soittimisto koostuu rummuista, bassosta, pianosta, rytmikitarasta ja kolmesta saksofonista, puhaltimet tosin soittavat ainoastaan toisessa ja neljännessä säkeistössä. Soolon rytminen fraseeraus on erittäin vaihtelevaa, ja myös venytysten sävelkorkeuksissa on melkoisesti hiuksenhienoja eroja, niinpä tämän kitarasoolon transkribointi oli varsin työläs urakka. Suurin osa fraaseista on myös ajallisesti melko pitkiä, kestäähän yksi tahti miltei viisi sekuntia. Slurreja on aivan muutama, liu'utuksia vain yksi, mutta venytyksiä on sitten sitäkin runsaammin. Soolossa käytetään kaikkia kolmea sormitusta: alusta viidennen tahdin loppuun sormitus on B, kuudennen tahdin alusta yhdeksännen tahdin loppuun $\mathrm{C}$ ja kymmenennestä tahdista soolon loppuun $A$.

Soolo alkaa siis B-sormituksella lyhyellä koholla toisen laulusäkeistön viimeisen iskun toisella kahdeksasosalla. Aluksi noustaan g-kieleltä keskisormella soitetusta kvintistä b-kielelle nimettömällä soitettuun perusääneen, joka toistetaan, minkä jälkeen jatketaan edelleen ylöspäin $e^{1}$-kielellä etusormella soitettuun hieman ylennettyyn pieneen terssiin. Ääntä toistetaan pariin kertaan erittäin pienin kestovaihteluin, palataan takaisin perusääneen, jonka muutaman toiston jälkeen soitetaan vielä alaspäinen terssihyppy pienestä terssistä perusääneen. Viimeistä edellistä ääntä lukuunottamatta ei yksikään ääni fraasissa osu iskulliselle tahdinosalle.

Toinen fraasi alkaa noin puolen tahdin mittaisen tauon jälkeen hieman ennen toisen tahdin ensimmäisen iskun viimeistä kahdeksasosaa $\mathrm{e}^{1}$-kielellä nimettömällä soitetulla venytyksellä sävellajin kvinttiin. Venytys sidotaan aina tahdin kolmannelle iskulle saakka, minkä jälkeen soitetaan rock- ja blueskitaristeille erittäin tyypillinen soittokuvio: venytys, venytyksen laskeminen takaisin lähtösäveleen sekä alaspäinen slurri. Tahdin lopuksi ankkuroidaan etusormi $\mathrm{e}^{1}$ kielelle pienelle terssille, ja nimettömällä soitetaan ensin kvarti $e^{1}{ }_{-}$ kielellä ja lopuksi perusääni b-kielellä. Fraasi jatkuu kolmannen tahdin alussa kahdella hieman ylennetyllä pienellä terssillä ja perusäänen repetitiolla. Lopuksi perusääni jätetään soimaan lähes kokonaisen iskun ajaksi, kunnes fraasi lopulta päättyy ylöspäiseen hyppyyn hieman ylennettyyn pieneen terssiin. Tässäkin fraasissa on ainoastaan yksi sävel soitettu iskullisella tahdinosalla.

Toisen ja kolmannen fraasin välissä on miltei kolme iskua pitkä 
tauko. Neljäs tahti alkaa aivan samoin kuin toinenkin, mutta nyt venytys katkaistaan heti alkuunsa ja ikään kuin otetaan uudelleen vauhtia etusormella soitetusta pienestä terssistä ja nimettömällä soitetusta kvartista ennen hieman alennetun kvintin polyrytmistä toistoa neljännen tahdin lopussa. Viidennen tahdin alussa fraasi jatkuu yllättäen ylennetyn suuren terssin ja kvartin vaihtelulla sekä edelleen tavanomaisemmin perusäänen ja pienen terssin toistoilla. Ylennetty suuri terssi tahdin ensimmäisellä iskulla on jälleen osoitus Buddy Guyn mieltymyksestä voimakkaisiin dissonansseihin, sillä säestyksessä on subdominanttipohjainen pienseptimisointu. Kun b-kielellä soitettu perusääni on muutaman toistokerran jälkeen jätetty soimaan tahdin puolivälissä ja sidottu synkooppina kolmanteen iskuun, on tahdin ja fraasin loppu soitettu $\mathrm{e}^{1}$-kielellä: etusormella pieni terssi, nimettömällä kvartti ja venytys kvinttiin, hyppy takaisin pieneen terssiin, kvarttisynkooppi ja lopuksi paluu pieneen terssiin. Lähes kaksi tahtia pitkässä fraasissa on kolme säveltä soitettu iskuille. Näistä yhdenkään kesto ei yllä edes kahdeksasosaan, mutta äänet ovat silti mielenkiintoisia: alennettu kvintti, ylennetty suuri ja ylennetty pieni terssi.

Tahdissa 6 Guy vaihtaa C-sormitukseen. Soolon neljäs fraasi alkaa kuudennen tahdin toisen iskun ensimmäisen kahdeksasosan viimeisellä kolmanneksella $C$-sormitukselle ehkä hieman yllättävällä äänellä, g-kielellä soitetulla pienellä septimillä, ja jatkuu edelleen etusormella $b$-kielellä soitetulla perusäänellä, joka jätetään soimaan. Perusääni lyödään uudestaan kuudennen tahdin kolmannella iskulla, minkä jälkeen toistetaan nimettömällä venyttäen soitettua suurta terssiä. Tahdin lopussa siirrytään $g-$ ja $b$-kielille kolmioon $a^{1} \rightarrow c^{2} \rightarrow d^{2}$, joka tyypilliseen tapaan purkautuu seitsemännen tahdin alussa perusääneen.

Viides fraasi alkaa kahdeksannen tahdin jälkipuoliskolla b-kielellä nimettömällä toistettavalla kokoaskeleen laajuisella venytyksellä sekunnista suureen terssiin, ja loppuosa onkin taas soitettu äänillä $\mathrm{a}^{1}$, $c^{2}$ ja $d^{2}$. Kuudes fraasi alkaa lyhyen tauon jälkeen kahdeksannen tahdin toisen iskun toisella kahdeksasosalla, ja tällä kertaa koko fraasi kulkee tuon kolmion äänillä.

Yhdeksännen tahdin alussa on soolon viimeinen C-sormituksella soitettu fraasi, ja se koostuu sormituksen tyypillisimmistä kuvioista. Ensin venytetään nimettömällä $e^{1}$-kielellä kvintistä suureen sekstiin ja palataan venytyksen lähtösäveleen, minkä jälkeen käydään kvartissa ennen pudottautumista b-kielelle venyttämällä soitettuun suureen 
terssiin. Loppuosa fraasista on jälleen soitettu kolmion $a^{1} \rightarrow c^{2} \rightarrow d^{2}$ äänillä, kunnes aivan lopuksi venytetään sekunnista vielä suureen terssiin. Fraasi on dynaamisesti varsin vaikuttava: se alkaa iskuille soitetuilla pitkillä äänillä, joista ensimmäinen on soolon korkein sävel, mutta jatkossa aika-arvot pienenevät ja samalla myös äänten rytmitys muuttuu vaihtelevammaksi.

Kymmenennessä tahdissa Guy vaihtaa A-sormitukseen. Ensimmäinen ääni on pitkähkö kokoaskeleen venytys b-kielellä pienestä septimistä perusääneen. Etusormi ankkuroidaan $\mathrm{e}^{1}$-kielelle perusäänelle, otetaan vauhtia pienestä terssistä ja soitetaan perusäänestä ylöspäinen ja terssistä alaspäinen slurri. Edelleen etusormella otetaan kvintti b-kielellä ja perusääni $\mathrm{e}^{1}$-kielellä, minkä jälkeen lähdetään mollipentatonista asteikkoa alaspäin. Kvintti ja kvartti soitetaan ensin tavallisesti ja heti perään venyttämällä, ja molemmat venytykset tapahtuvat g-kielellä. Fraasi päättyy tahdin 11 alussa perusäänen muutamaan toistoon d-kielellä.

Lyhyt fraasi 11. tahdin keskellä nousee pienillä aika-arvoilla kromaattisesti pienestä terssistä kvarttiin g-kielellä ja laskeutuu saman tien suuren terssin kautta d-kielellä soitettavaan perusääneen. Myös seuraava fraasi on hyvin samantyyppinen: kromaattinen nousu 11. tahdin lopulta pienestä terssistä kvinttiin tahdin 12 alussa. Tahdin 11 kolme viimeistä ääntä ovat alle puoliaskeleen päässä toisistaan, mikä osaltaan vielä lisää yhdensuuntaiseen kromaattiseen kulkuun muutenkin kuuluvaa painetta.

Myös soolon kaksi viimeistä fraasia ovat erittäin lyhyitä. Tahdin 12 toisella iskulla alkava fraasi ankkuroituu kvintin ympärille, ja tahdin lopussa on vielä kuudestoistaosa -trioleina soitettu alaspäinen mollipentatoninen asteikkokulku kvintistä pieneen terssiin, kvarttihyppy alaspäin d-kielellä soitettuun pieneen septimiin, ja viimeinen ääni on tyypilliseen tapaan perusääni.

\section{Sormitukset}

Buddy Guyn bluessooloista olen siis löytänyt kolme erilaista sormitusta, jotka olen nimennyt peräkkäisillä suurilla aakkosilla $A, B$ ja $C$ (ks. esimerkki 2, sivu 107). Sormituksista yksikään ei ole niin yleinen, että se esiintyisi otoksen jokaisessa soolossa. Esimerkiksi soolo kap- 
paleessa Goin' Home kulkee viimeistä lyhyttä fraasia lukuunottamatta B-sormituksella. Merkillepantavaa on, että otoksen hitaiden kappaleiden sooloista jokaisessa on käytetty kaikkia sormituksia.

Esimerkki 3. Eri sormitusten osuudet kaikissa nuotintamissani kitarasooloissa. Ensimmäinen luku ilmaisee, kuinka monessa tahdissa sormitusta on käytetty, ja suluissa ovat absoluuttiset tahtinumerot. Suluissa mahdollisesti oleva 0-tahti tarkoittaa soolon aloittavaa kohoa. Koska mukaan on laskettu kaikki ne tahdit, joissa kutakin sormitusta on käytetty, näyttää tahtien lukumäärä monissa sooloissa olevan enemmän kuin 12. Harha paljastuu katsottaessa sulkujen sisään. Esimerkiksi So Sad This Morning -kappaleen kitarasoolon tahtien määräksi näyttäisi saatavan 15 , koska mukana on kohotahti 0 ja sormitusten vaihdot tapahtuvat tahtien 4 ja 11 sisällä.

\begin{tabular}{|l|l|l|l|}
\hline SOOLO \SORMITUS & \multicolumn{1}{l}{ A } & \multicolumn{1}{l|}{ B } \\
\hline Nopeat ja keskitempoiset: & & & \\
WATCH YOURSELF \#1 & $6(7-12)$ & $7(1-7)$ & 0 \\
WATCH YOURSELF \#2 & $4(8-11)$ & $7(0-4,11-12)$ & $4(4-7)$ \\
CHECKING ON MY BABY \#1 & $3(9-11)$ & $9(0-8)$ & 0 \\
CHECKING ON MY BABY \#2 & 0 & $5(0-4)$ & $7(5-11)$ \\
GOIN' HOME & $2(11-12)$ & $11(1-11)$ & 0 \\
LITTLE BY LITTLE & $12(1-12)$ & 0 & 0 \\
Hitaat: & & & \\
A MAN AND THE BLUES & $2(11-12)$ & $6(0-5)$ & $6(6-11)$ \\
SWEET LITTLE ANGEL & $3(10-12)$ & $6(0-5)$ & $4(6-9)$ \\
SO SAD THIS MORNING & $2(11-12)$ & $5(0-4)$ & $8(4-11)$ \\
\hline
\end{tabular}

Sormitusten järjestys soolossa on periaatteessa aina sama: $B \rightarrow C \rightarrow A$. C-sormitus saattaa jäädä välistä pois, jolloin B-sormituksesta siirrytään suoraan A-sormitukseen. C:stä ei siirrytä yhdessäkään soolossa B:hen eikä A:sta C:hen. Vain yhdessä otoksen sooloista palataan lopussa täyden ympyrän jälkeen vielä takaisin aloitussormitukseen. Sormitusta ei kertaakaan vaihdeta fraasin keskellä vaan aina välissä. Lukuunottamatta kokonaisuudessaan A-sormituksella soitettavaa Little by Little -kappaleen sooloa alkavat kaikki B-sormituksella. Lopetussormitus on useimmiten $A$ : se on ambitukseltaan laajin ja ulottuu matalimmalle. Kaikista sooloista B-sormituksella on soitettu noin puolet, ja toinen puoli jakautuu melko tasaisesti kahdelle 
muulle sormitukselle, joista $A$ on yleisempi nopeissa kappaleissa ja $C$ hitaissa. On mielenkiintoista, että C-sormitus, joka hitaissa sooloissa on kaikkein tavallisin, on nopeista sooloista käytössä ainoastaan kahdessa.

\section{Blueskitarasoolon rakenne pääpiirteissään}

Buddy Guyn kitarasooloille on ominaista kirkas, selvästi taustasta erottuva sointi ja etenkin hitaissa kappaleissa kiihkeä intensiteetti. Käytössä on kolme erilaista asemasormitusta, joiden keskinäinen järjestys on periaatteessa aina sama, vaikkakaan kaikkia ei välttämättä käytetä jokaisessa yksittäisessä soolossa. Soolot koostuvat selkeästi toisistaan erottuvista fraaseista, joiden pituudet vaihtelevat yhdestä soitetusta äänestä yli kahteen tahtiin. Aseman ja sen myötä sormituksen vaihto tapahtuu aina fraasien välissä.

Näin pienen otoksen perusteella ei tietenkään voi tehdä tyhjentäviä yleistyksiä blueskitaransoitosta tai edes Buddy Guyn tyylistä. Mitään periaatteellista estettä ei ole esimerkiksi sille, etteivätkö nämä sormitukset voisi olla jossain toisessakin järjestyksessä tai etteikö joitakin muita sormituksia voisi olla käytössä ja soolo silti kuulostaisi tyylinmukaiselta bluessoololta. Joka tapauksessa korpuksen soolojen monet piirteet ovat keskenään niin yhtenäisiä, että puhe Buddy Guylle ominaisista tyylipiirteistä on mielekästä ja poikkeamat näistä tuloksista voivat olla vain sääntöä vahvistavia poikkeuksia.

Soolo alkaa tavallisimmin B-sormituksella, ja yleisin yksittäinen aloituskuvio on kvarttihyppy g-kielellä soitetusta kvintistä b-kielellä soitettuun perusääneen sekä edelleen $\mathrm{e}^{1}$-kielellä soitettuun pieneen terssiin, jota mahdollisesti venytetään. Kahta jälkimmäistä ääntä voidaan myös vaihdella ja toistaa, kuten on tehty esimerkiksi Sweet Little Angelin pitkähkössä aloitusfraasissa. Mikäli B-sormituksella alkavan soolon ensimmäinen ääni ei ole g-kielellä soitettu kvintti, se on erittäin todennäköisesti b-kielellä soitettu perusääni. Hitaiden kappaleiden sooloissa pari ensimmäistä fraasia ovat tyypillisesti lyhyehköjä, minkä jälkeen soitetaan yksi pitempi fraasi ennen siirtymistä Csormitukseen. Nopeissa kappaleissa ei tällaista asteittaista kasvattamista tapahdu.

Hitaissa sooloissa B-sormitus jatkuu miltei soolon puoliväliin, nopeissa vaihtelua on enemmän: yhdessä soolossa sitä ei ole käytetty 
lainkaan, yhdessä sillä on soitettu miltei koko soolo. Niissä nopeissa kappaleissa, joissa B-sormituksesta siirrytään suoraan A-sormitukseen, saattaa viimeinen B-sormituksella soitettu kuvio olla alaspäinen g-kielellä soitettuun kvinttiin päättyvä kulku. Yhdessä korpuksen sooloista palataan lopussa C- ja A-sormituksilla soitettujen osien jälkeen vielä $B$-sormitukseen, jolla soitetaan soolon aivan viimeinen perusääneen päättyvä fraasi.

Kaikissa korpuksen hitaiden kappaleiden kitarasooloissa siirrytään B-sormituksesta $C$-sormitukseen. Nopeissa kappaleissa näin tehdään kahdessa viidestä B-sormituksella alkavasta soolosta, muissa siirrytään suoraan A:han. C-sormituksen kuviot koostuvat selkeimmin valmiista palasista, mutta vastapainoksi niissä on eniten rytmistä vaihtelua. Tyypillisiä kuvioita ovat 1) liikkuminen kolmion seksti $\rightarrow$ perusääni $\rightarrow$ sekunti sävelillä, 2) venytys b-kielellä sekunnista ters-

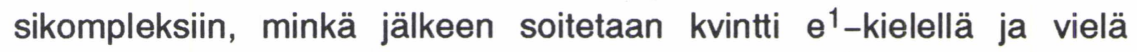
mahdollisesti perusääni b-kielellä sekä 3) venytys $e^{1}$-kielellä kvintistä sekstiin tai pieneen septimiin, minkä jälkeen soitetaan äänet (kvintti $\rightarrow$ ) kvartti $\rightarrow$ kvintti $\rightarrow$ venytys b-kielellä terssikompleksiin.

Kahta nopeaa kappaletta luukuunottamatta on lopetussormitus sooloissa aina A, ja yhdessä korpuksen kappaleista sillä on soitettu koko soolo. Se sopiikin erityisen hyvin soolon loppuun, koska se yltää yli oktaavia matalammalle kuin seuraavaksi matalimman sormituksen alin ääni. Tyypillinen lopetuskuvio koostuu lyhyehköistä, nopein aikaarvoin soitettavista alaspäisistä mollipentatonisista asteikkokuluista, ja yleensä soolo loppuu perusääneen tai kvinttiin, joskus myös molliterssiin.

\section{Loppupäätelmiä analyysin tuloksista}

Kitaransoittoa ja improvisointia käsittelevässä kirjallisuudessa on bluesimprovisaatiota yleensä pidetty asteikkopohjaisena toimintana (esim. Backlund 1983:68; Saastamoinen 1974:238). Analyysini Buddy Guyn soittotavasta ei mielestäni tue tätä käsitystä. Pikemminkin näyttäisi siltä, että soittajalla on käytettävissään tietty varasto erilaisia motiiveja ja kuvioita, jotka esimerkiksi Guyn tapauksessa tuntuvat perustuvan määrättyihin sormituksiin ja soittotapoihin. Näitä kuvioita tyylinmukaisesti varioimalla syntyy sitten improvisoitu bluessoolo.

Edelläoleva ei tietenkään sulje pois sitä, etteikö Buddy Guyn ki- 
tarasoolojen pohjalta olisi konstruoitavissa yhtenäistä asteikkoa, jolloin kyseeseen saattaisi tulla esimerkiksi jonkinlainen molli- ja duuripentatonisen asteikon yhdistelmä. Koska Guyn käyttämät kolme sormitusta kuitenkin poikkeavat toisistaan niin sävelvarastoltaan kuin luonteeltaankin ja koska nähdäkseni soittimellisuus ohjaa sävelten valintaa mitä suurimmassa määrin, en katso olevan erityisen mielekästä yrittää rakentaa yhtä yhtenäistä asteikkoa. Missään tapauksessa sellaisen asteikon selitysvoima ei voisi nousta kovin korkeaksi.

Yhden kitaristin soittotavasta ei tietenkään voida tehdä pitkälle meneviä koko tyylisuuntaa koskevia yleistyksiä, ja jopa Guyn osalta otosta voidaan ehkä pitää suppeahkona. Korpuksen soolojen monet piirteet ovat kuitenkin siinä määrin yhtenevät, että melkoisella varmuudella voidaan puhua tyylille ominaisista piirteistä kuten esimerkiksi sormitusten sävel- ja soittokuviovalikoima sekä järjestys soolossa. Kattavampi teoria Buddy Guyn soitosta voitaisiin saada aikaan vain laajentamalla analyysimateriaalia huomattavasti esimerkiksi muihinkin kuin 12-tahtisiin kitarasooloihin tai ottamalla mukaan laulusäkeiden väleihin soitetut täytefraasit.

\section{Lähteet}

Backlund, Kaj (1983), Improvisointi pop/jazzmusiikissa. Helsinki: Musiikki Fazer.

Eklund, Björn (1987), Bluesfraser hos Eric Clapton. Pro gradu -työ. Säilytyspaikka: Helsingin yliopiston musiikkitieteen laitos.

Evans, David (1982), Big Road Blues: Traditions And Creativity in the Folk Blues. Berkeley-Los Angeles: University of California Press.

Fahey, John (1970), Charlie Patton. Lontoo: Studio Vista.

Hannusch, Jeff (1989), "Soul Blues And Modern Trends". The Blackwell Guide to Blues Records, Paul Oliver (toim.): 297-320. Oxford-Cambridge: Basil Blackwell.

Iltanen, Kimmo (1992), Buddy Guyn kitarasoolot ja bluesin olemus. Pro gradu -työ. Säilytyspaikka: Helsingin yliopiston musiikkitieteen laitos.

Kjellberg, Erik (1976), "blue note". Otavan iso musiikkitietosanakirja, 1. osa. Keuruu: Otava.

Obrecht, Jas (1990), "Buddy Guy". Guitar Player 4/1990: 32-48. 
Oliver, Paul - Harrison, Max - Bolcom, William (1986), The New Grove Gospel, Blues and Jazz. Lontoo \& Basingstoke: Macmillan.

O'Neal, Jim - Zorn, Tim (1970), "Living Blues Interview: Buddy Guy". Living Blues no. 2, Jim \& Amy O'neal (toim.):3-9. University of Mississippi.

Rowe, Mike (1973), Chicago Breakdown. Lontoo: Eddison. Julkaistu 1981 muuttamattomana nimellä Chicago Blues: The City \& The Music. New York: Da Capo Press.

Saastamoinen, Ilpo (1974), Kitarakirja. Helsinki: Tammi.

Titon, Jeff (1979), Early Downhome Blues. Urbana-Chicago-Lontoo: University of Illinois Press.

1) Regrettably they [other analysts] do not agree what the "blue note" is or how it is used. Some think it is one pitch, others a group of pitches; still others believe it is a slur. Some locate it as a "flatted" third or seventh which replaces the major interval; others include both the "flatted" (sometimes distinguished from "minor") and the major interval. 


\section{Iltanen}

Liite 1.

GO I N, HOME

(Willie Dixon: Arc Music Corp./Hoochie Coochie Music Admin. by Bug-BMI)

Aäni tety 1967.

Transkript io CD: $1 \mathrm{tä} \mathrm{Buddy} \mathrm{Guy:} \mathrm{Left} \mathrm{My} \mathrm{Blues} \mathrm{In} \mathrm{San} \mathrm{Francisco;}$

CHD-31265, 1967, 1987 HCA Records, Universal City, CA, USA;

alun perin julkaistu Chess-merkillä koodilla Chess LP 1527, 1967.

Transkriptio: Kimmo Iltanen.

Alkuperäinen sävellaji: g-blues.
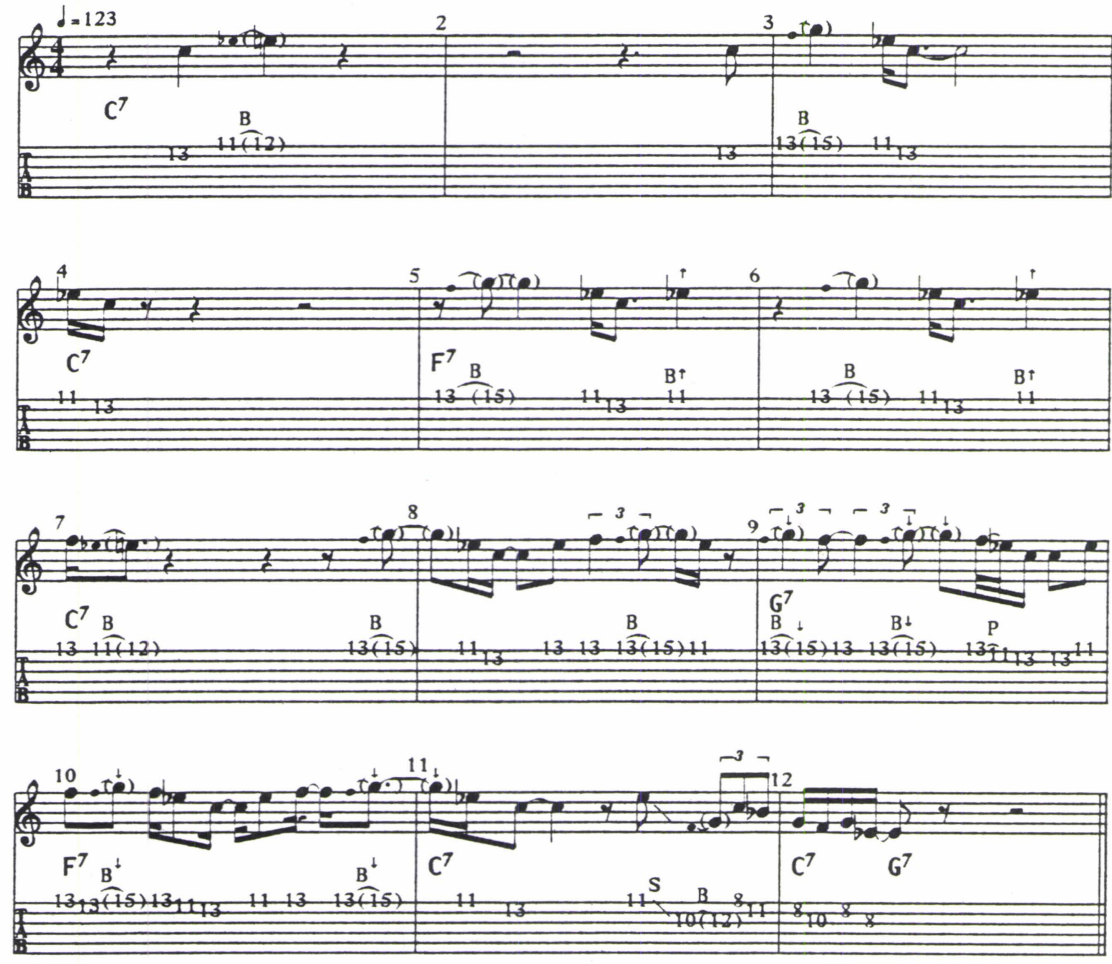
Liite 2.

SWEET LITTLE ANGEL

(B.B.King, Yodern Yusic, BMI)

Äänitetty 1967

Transkriptio CD: 1 tä Buddy Guy: A Man And The Blues;

VMD-79272, 1987 Vanguard Records, a Welk Record Group Company, Santa Monica, CA, USA;

alun perin julkaistu 1967.

Transkriptio: Kimmo I1tanen.

Alkuperäinen sàvellaji: d-biues.
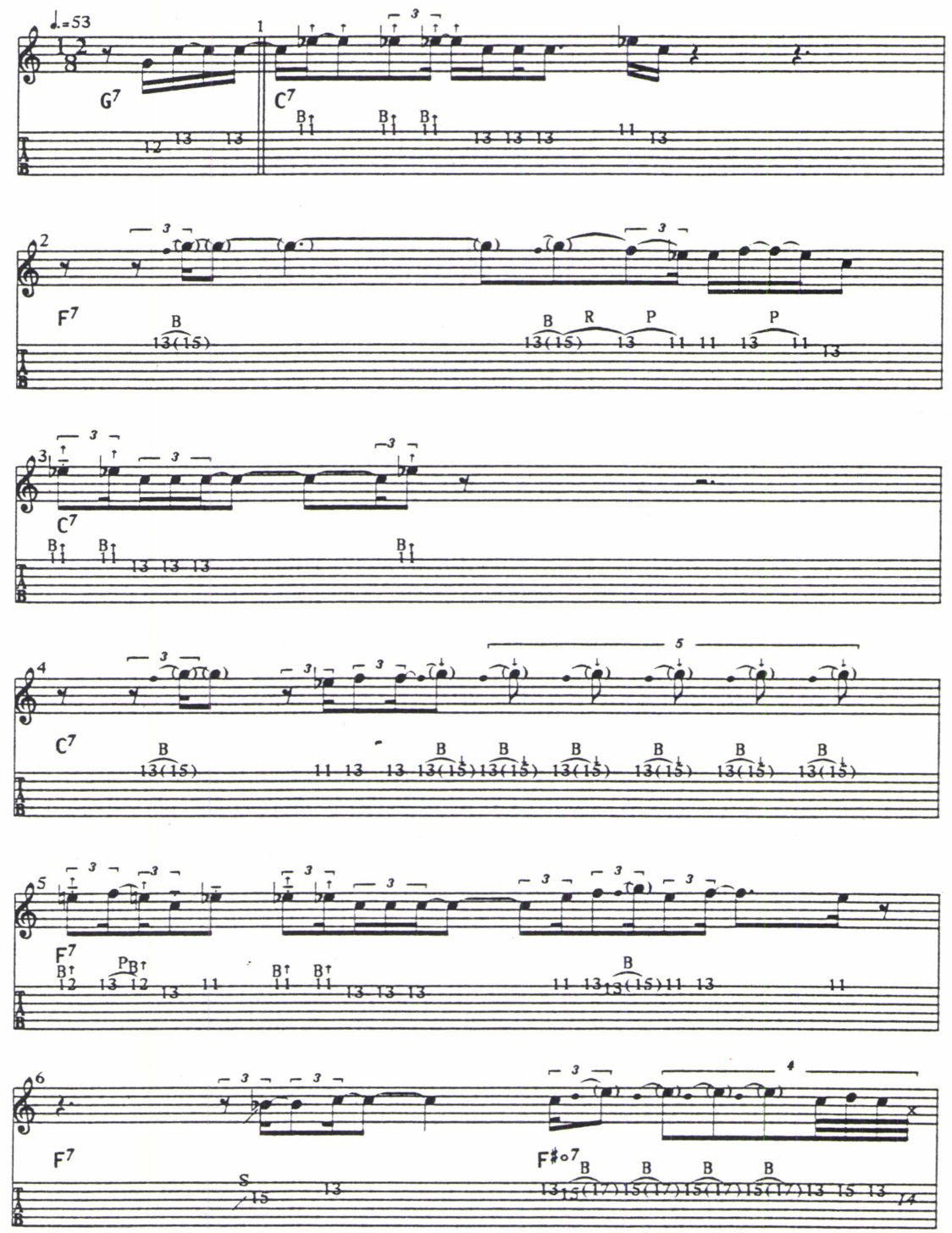


\section{Iltanen}
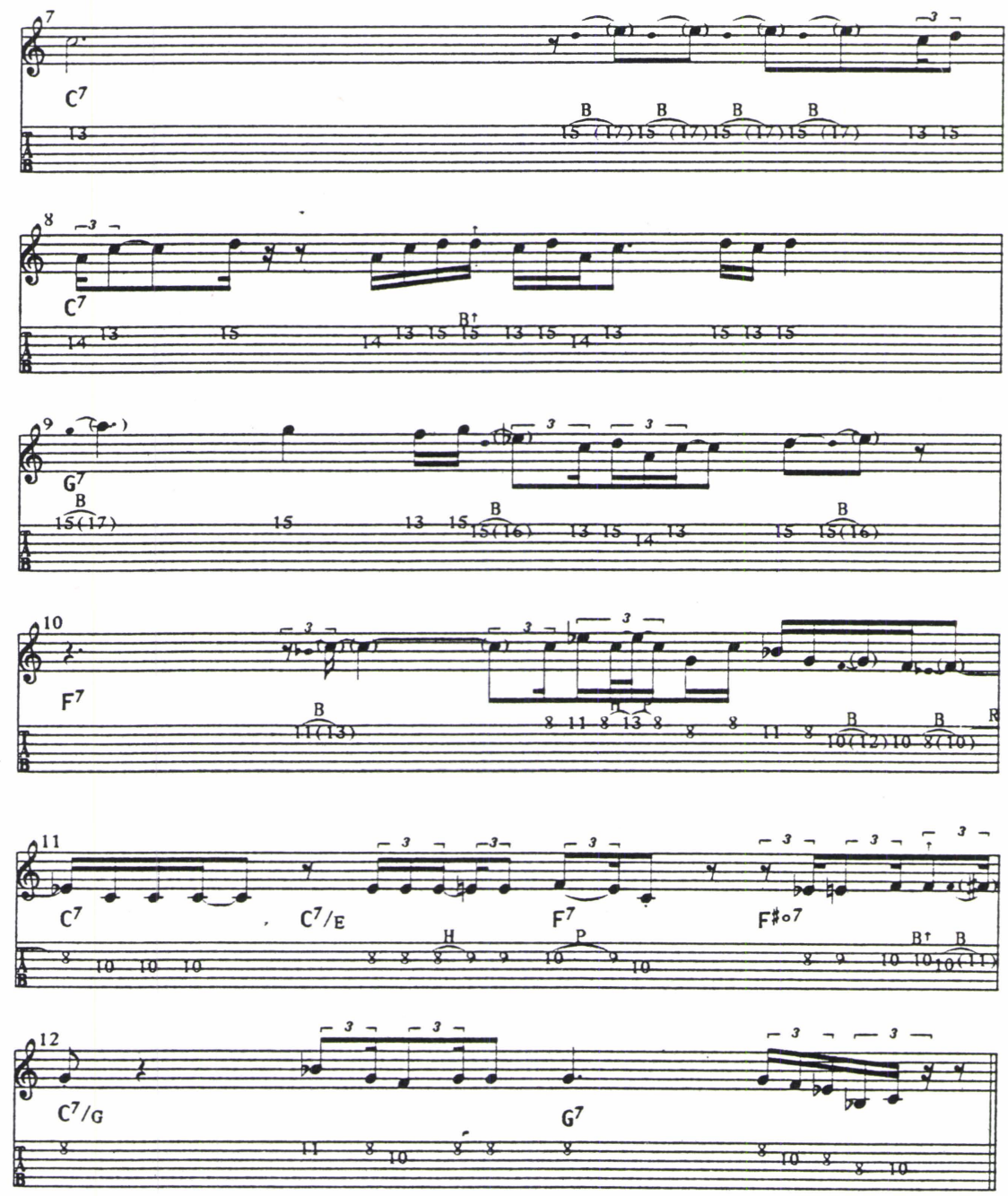


\section{Liite 3. Notaatio- ja tabulatuurisymbolit:}

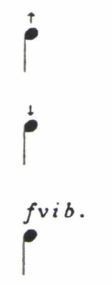

\footnotetext{
= sävel hieman ylennetty.

= sävel hieman alennettu.
}

Ti lapäisten ylennys-, alennus- ja palautusmerkkien vaikutus kestää yleisen käytännön mukaisest $i$ tahdin loppuun tai seuraavaan t i lapä ismerkki in. Milloin äanen korkeutta on merkitty (myös) nuolella, on merkki kuitenkin ainutkertainen kokonaisuus, eikä sen vaikutus ulotu kyseistä nuottia pitemmälle.

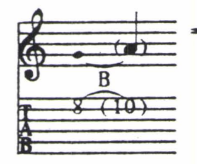

venytys. Nuotti ilman vartta osoittaa äänen, joka kieltä venyttämällä nostetaan suluissa olevan nuotin ilmaisemaan soivaan sävelkorkeuteen. Tabulatuuri esittäa kitaran kieliä ylhäaltä alas ohuimmasta paksuimpaan, numerot merkitsevat otelaudan nauhoja. Esimerkissa painetaan toiseksi ohuinta kieltä 8: nnen nauhan kohdalta (standardivirityksella g..-sävel) ja kieltä venyt ämallä nostetaan sävelkorkeus vastaamaan aäntä, joka syntyisi kieltä painettaessa 10 : nneltä nauhalta ( $a^{1-}$ sävel). ( $\mathrm{B}=$ bend. $)$
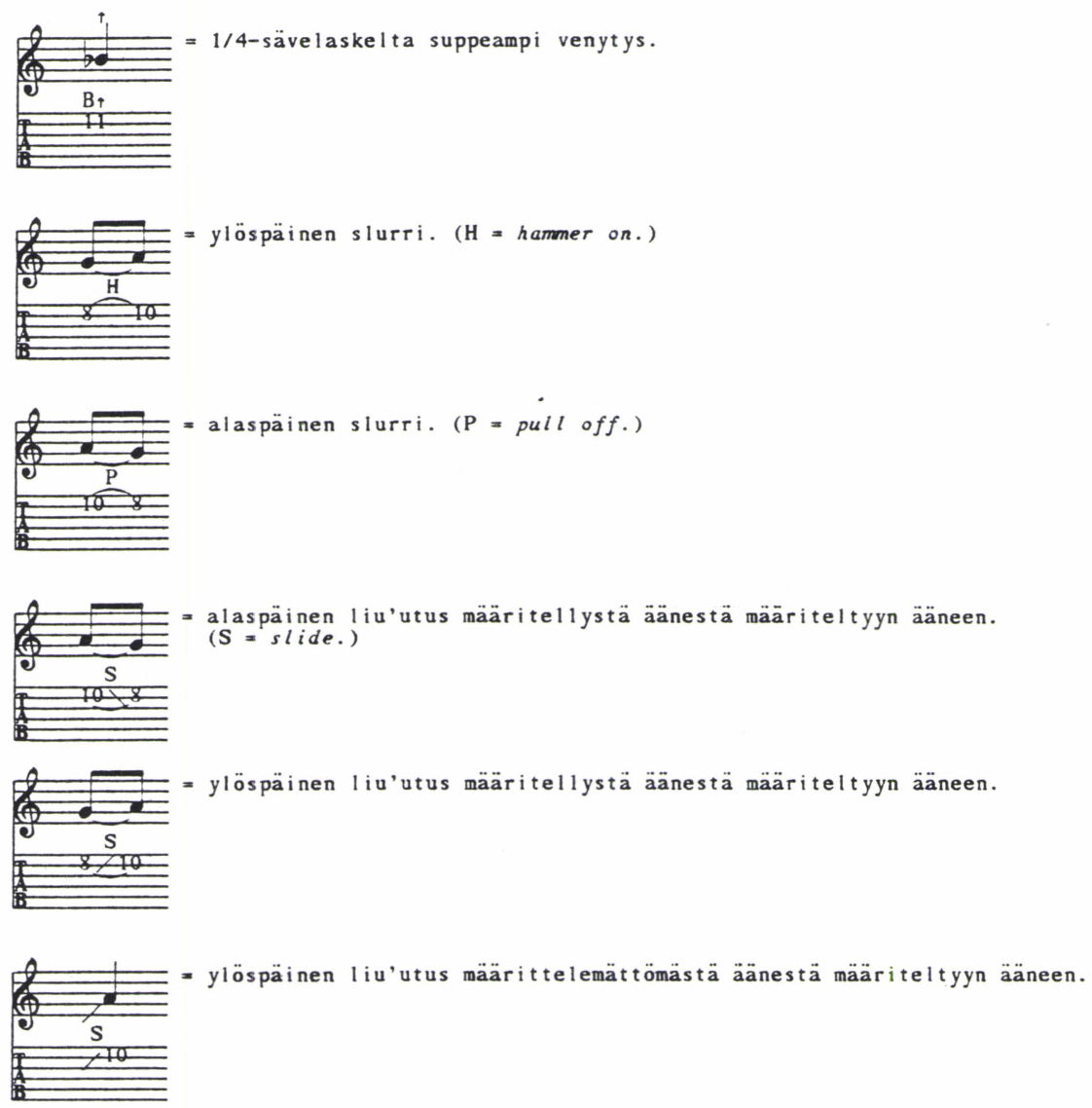


\section{Iltanen}

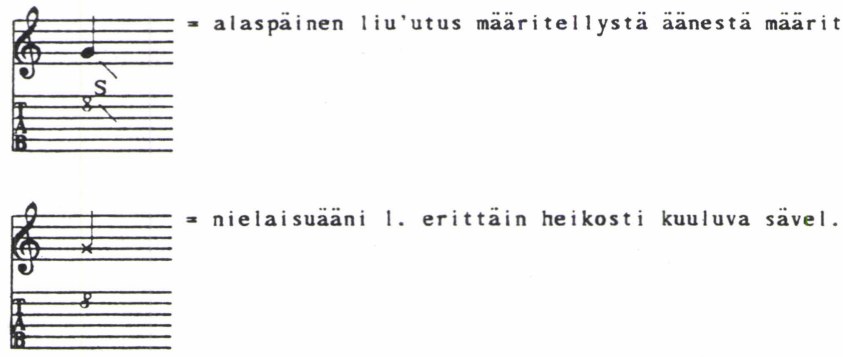

Huom! Tabulatuurivi ivaston numerot vi ittaavat aina siihen kieleen, jota ne leikkaavat. Vaikka seuraavan esimerkin numerot ovat eri tasossa, soitetaan kaikki äänet bkielellä. Merkintätapaa on käytetty erottamaan numeroita toisistaan, milloin nuotit ovat niin tiheässä, ettei numeroiden väli in mahdu välilyöntiä.

Esim.

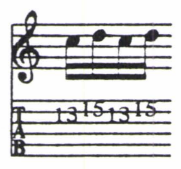

Yleisestä käytännöstä poiketen kitaranuotit on merkitty soivaan sävelkorkeuteen. 